\title{
COMPARISON OF FUNCTIONALITY OF TYPE A AND B GUIDE RAILS OF STEEL ROAD SAFETY BARRIERS
}

DANIEL BRONISLAW NYCZ*

Technical Institute, Jan Grodek State Vocational Academy, Sanok, Poland

Received 21 October 2017; accepted 23 August 2018

\begin{abstract}
The subject of the work is types A and B guide rails of steel road barriers. An experimental three-point bend test on a segment of a B-type guide rail was conducted for experimental validation of the numerical modelling of the guide rail. Numerical modelling of bend tests on A and B guide rail segments was performed. It was shown that the load-bearing capacity and energy absorbed during bending for guide rail $\mathrm{A}$ are more than for guide rail B, respectively. Numerical TB32 crash tests (a $1500 \mathrm{~kg}$ vehicle, $110 \mathrm{~km} / \mathrm{h}$ impact speed, $20^{\circ}$ impact angle) were carried out in the LS-Dyna system. The Dodge Neon vehicle model was downloaded from the National Crash Analysis Centre in the United States. A $60 \mathrm{~m}$ long barrier section is composed of A or B guide rail segments, SIGMA-100 posts, trapezoidal supporting elements and rectangular pads. Each segment has a total length of $4.30 \mathrm{~m}$ and an efficient length of $4.00 \mathrm{~m}$. SIGMA-100 posts are $1.90 \mathrm{~m}$ long and spaced by $2.00 \mathrm{~m}$. The whole barrier is assembled with M16 screws with a spherical head and a nose, strength class 4.6. The simulated crash tests showed slight differences in the functionality of guide rails A and B regarding the TB32 crash test.
\end{abstract}

Keywords: comparative analysis, numerical modelling, road safety barriers, simulation, steel guide rails, TB32 crash test.

* Corresponding author. E-mail: dnycz@pwsz-sanok.edu.pl

Copyright ( $(2018$ The Author(s). Published by RTU Press

This is an Open Access article distributed under the terms of the Creative Commons Attribution License (http://creativecommons.org/licenses/by/4.0/), which permits unrestricted use,

distribution, and reproduction in any medium, provided the original author and source are credited. 


\section{Introduction}

Road safety barriers, part of the essential equipment for road safety, are used to ensure road safety and to protect the lives of vehicle users and people in adjacent areas. They are used in places where driving off the road or crossing the separation strip may compromise the safety of traffic participants (Mikolajow, 2006).

In work (Mikołajów, 2006), it was emphasized that road safety barriers are designed using non-standard calculation methods since their effectiveness and proper operation depend on the construction details. Therefore, road barriers are tested using experimental crash tests by the group of standards EN 1317 European Road Restraint Systems. Standard $P N-E N$ 1317-5+A2:2012 introduces the possibility of certifying road safety barriers modified slightly about the so-called parental barrier. The latter is certified experimentally. This possibility reduces the number of expensive experimental crash tests.

Most steel barriers have guide rails made of profiled steel strips with two or three ribs. Some barriers have a guide rail with a crosssection other than profiled strips, e.g., a semi-closed or closed crosssection. Road barriers are also made of aluminium (guide rails made of aluminium sections). Steel barriers were introduced in the early 1930s in the United States. The first barriers had an arc-shaped guide rail (Tuthill barriers). Next, Armco and Bethlehem Steel system guide rails were introduced, now known as Type A guide rails. Later, the Type B guide rail was introduced (Mikolajow, 2006).

In work (Transportation Officials, 2011) published by the American Association of State Highway Transportation Officials (AASHTO), two types of steel guide rails, $\mathrm{W}$-beam and Box-beam, are distinguished. The W-beam guide corresponds to type A.

In the present study, two basic types of steel guide rails, i.e., $\mathrm{A}$ and $\mathrm{B}$, were analysed. The work includes:

1. Experimental three-point bend test of type B guide rail segment;

2. Numerical modelling and simulations of three-point bend tests of type $A$ and $B$ guide rail segments;

3. TB32 crash test simulation on selected steel road barrier rail with type $A$ and $B$ guide rail.

The TB32 crash test uses a $1500 \mathrm{~kg}$ vehicle, colliding at the speed of $110 \mathrm{~km} / \mathrm{h}$ at an impact angle of $20^{\circ}$ to the road safety barrier (PN-EN 1317-2:2010).

The numerical modelling of crash tests on steel road safety barriers has been the subject of a number of publications, including Atahan (2002), Borovinšek, Vesenjak, Ulbin, \& Ren (2006, 2007), Nasution, Siregar, Fuad, \& Adom (2009), Ren, \& Vesenjak (2005), Klasztorny, Nycz, of Type $A$ and $B$ Guide Rails of Steel Road Safety

Barriers 
\& Romanowski (2015), and Klasztorny, Nycz, \& Szurgott, (2016)). Vehicle models built within the LS-Dyna system are taken from the National Crash Analysis Centre (NCAC). The simulateded crash tests analysed in works (Atahan, 2002; Borovinšek, Vesenjak, Ulbin, \& Ren, 2006, 2007; Nasution, Siregar, Fuad, \& Adom, 2009; Ren, \& Vesenjak, 2005) concern type $\mathrm{W}$ guide rails equivalent to type $\mathrm{A}$ guide rails.

\section{Types of guide rails covered by the study}

The guide rail is the most critical element of the steel road safety barrier. Its task is to take the impact of the vehicle and direct the vehicle back onto the roadway. During the crash test, the guide rail is gradually deformed in an elastoplastic way (GDDKiA, 2001). Steel strip guide rails are made in two types A and B, from profiled cold bent steel strips (Figure 1).

Guide rail A has rounded contact surfaces, and guide rail B - flattened (Figure 1). Guide rail B requires applying ribbing to one of the ends for the individual segments to adhere to each other flatly. Guide rail A is fabricated without ribbing, since it exhibits elasticity of the cross-section more than guide rail B (GDDKiA, 2001).

Figure 1 shows type A and B guide rails used by, among others, Stalprodukt (2006) in Bochnia, Poland. Each segment of the given guide rail has an overall length of $4.30 \mathrm{~m}$ and an efficient length of $4.00 \mathrm{~m}$. The guide rails are made from $3 \mathrm{~mm}$ thick steel strips, made of S235JR steel and subjected to hot-dip galvanizing. The weight of one segment of the A-type guide rail is $47.40 \mathrm{~kg}$, and the B-type guide rail is $44.10 \mathrm{~kg}$. There are five elongated holes for screws in type $A$ and $B$ guide rails guide rails to mount the guide rail on the barriers. Eight screws are required for guide rail $\mathrm{A}$ (elongated holes for screws horizontal and vertical; Figure 1a) and six screws for guide rail B (elongated and circular holes; Figure 1b) to connect two segments of the guide rails.

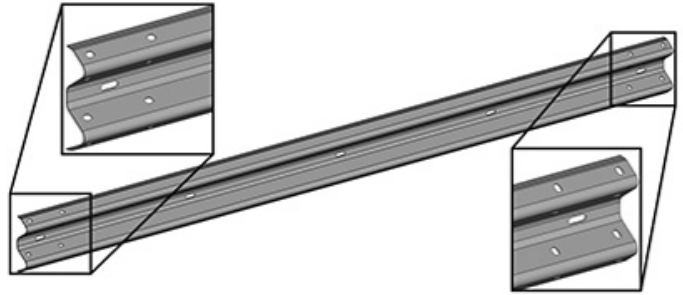

a) type $A$

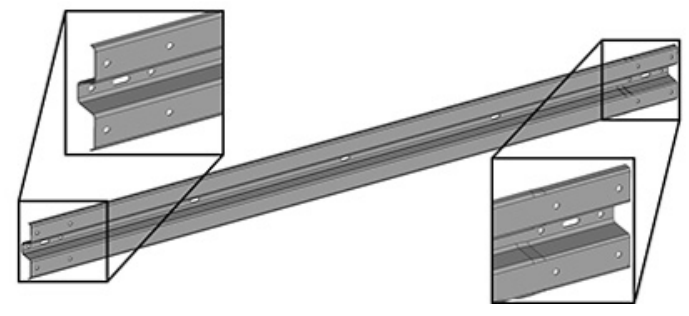

b) type $B$

Figure 1. Guide rails of steel road safety barriers 
Table 1. Geometric characteristics of a cross-section of type $A$ and $B$ guide rails

\begin{tabular}{ccccccc}
\hline $\begin{array}{c}\text { Type } \\
\text { of guide rail }\end{array}$ & $\begin{array}{c}\boldsymbol{A} \\
\mathbf{m m}^{2}\end{array}$ & $\begin{array}{c}\boldsymbol{I}_{\mathbf{y}} \\
\mathbf{m m}\end{array}$ & $\begin{array}{c}\boldsymbol{I}_{\mathbf{z}} \\
\mathbf{m m}^{4}\end{array}$ & $\begin{array}{c}W_{y 1} \\
\mathbf{m m}^{3}\end{array}$ & $\begin{array}{c}W_{y \| 1} \\
\mathbf{m m}^{3}\end{array}$ & $\begin{array}{c}W_{z} \\
\mathbf{m m}^{3}\end{array}$ \\
\hline $\mathrm{A}$ & $1.4150 \cdot 10^{3}$ & $1.0095 \cdot 10^{6}$ & $1.3199 \cdot 10^{7}$ & $2.4467 \cdot 10^{4}$ & $2.4185 \cdot 10^{4}$ & $8.6268 \cdot 10^{4}$ \\
\hline $\mathrm{B}$ & $1.3323 \cdot 10^{3}$ & $1.0981 \cdot 10^{6}$ & $9.2993 \cdot 10^{6}$ & $2.0782 \cdot 10^{4}$ & $4.3645 \cdot 10^{4}$ & $5.9995 \cdot 10^{4}$ \\
\hline
\end{tabular}

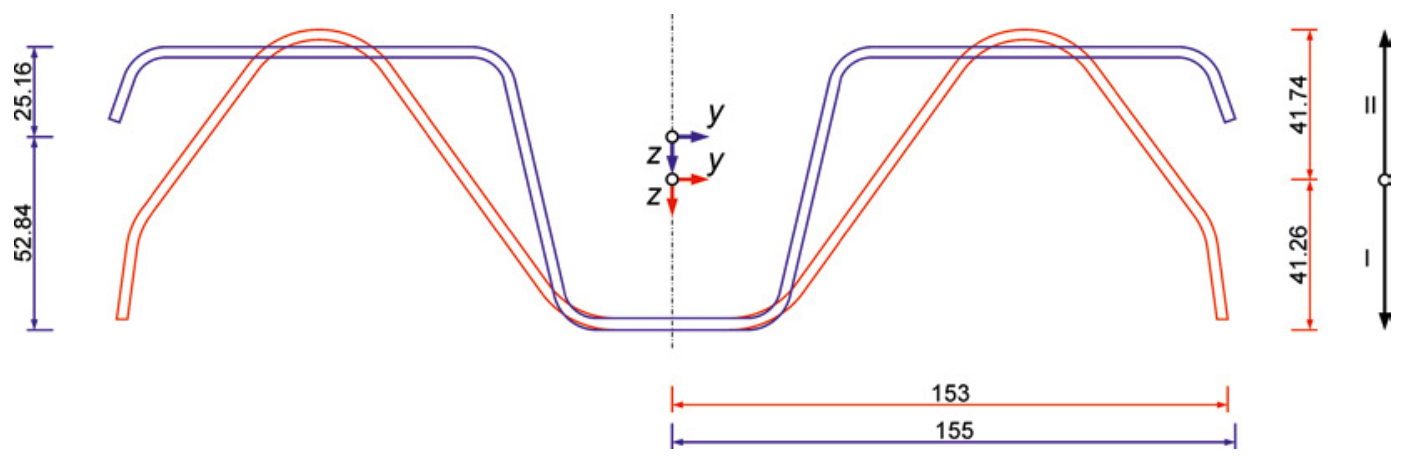

Figure 2. Comparison of cross-sections of type A and $B$ guide rails

In Table 1, the geometric characteristics of cross-sections of type A and B guide rails have been compiled. The symbols used are $A$ - crosssectional area in $\mathrm{mm}^{2}, I_{y}, I_{z}$ - principal central moments of inertia of the cross-section in $\mathrm{mm}^{4}$, and $W_{y}, W_{z}$ - indices of the cross-section flexural strength in $\mathrm{mm}^{3}$ (Figure 2). The type A guide rail has a cross-sectional area more than it is for the type B guide rail. For the B-type guide rail, the centre of gravity of the cross-section is located to the rail face closer than for the A-type guide rail. Hence, when bending the B-type rail back will be strenuous more than A-type rail back. For the type A guide rail, values of section indices for the bending, $W_{y 1}$ and $W_{y \mathrm{II}}$, are similar. Hence, when bending the face and back of this guide will be equally strenuous.

\section{Experimental three-point bend test of type $B$ guide rail segment}

The subject of the experimental investigation is a $2.00 \mathrm{~m}$ long B-type guide rail segment (from now on referred to as the validation segment), subjected to a three-point bend test. The research was carried out under 


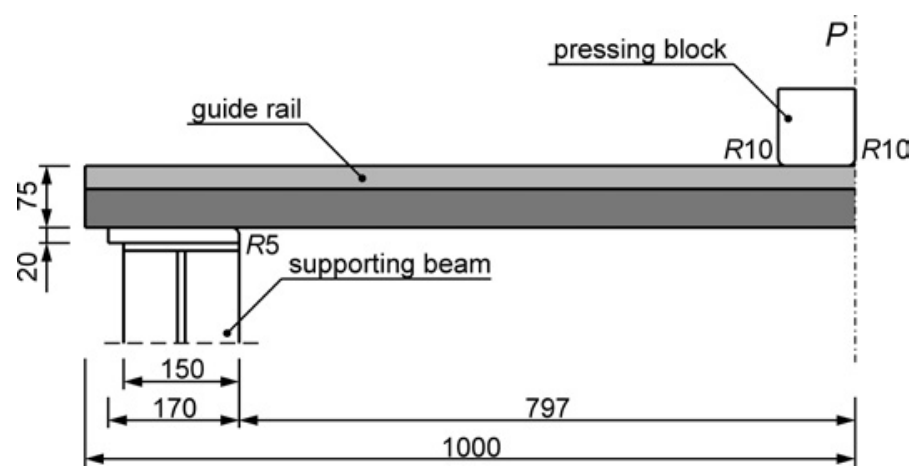

Figure 3. Scheme of stand for three-point bend test for validation segment of guide rail $B$

project PBS1/B6/14/2012 (ENERBAR) in the Strength of Materials and Structures Laboratory of the Dept. of Mechanics and Applied Computer Science of the Faculty of Mechanical Engineering, Military Academy of Technology in Warsaw, on a SATEC universal test machine with load bearing capacity of $1200 \mathrm{kN}$.

Figure 3 shows the scheme of the stand for three-point bend tests of the validation segment. The freely supported segment was under displacement-controlled loading on a $300 \mathrm{~mm}$ vertical section at a traverse

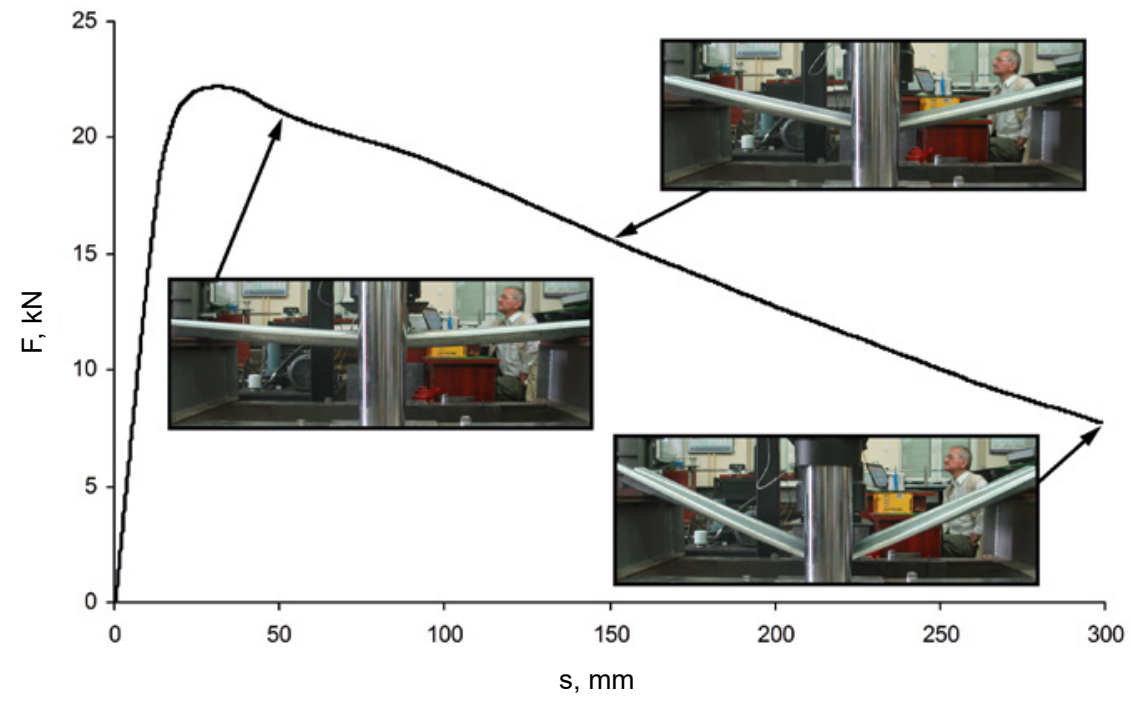

Figure 4. $F(s)$ chart obtained in three-point bend test of validation segment 


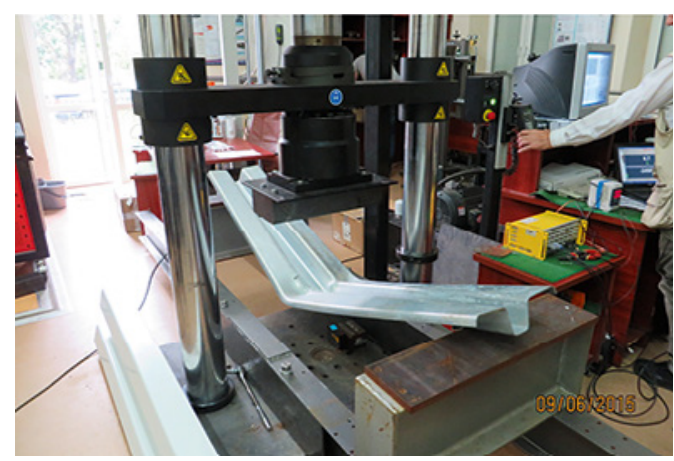

a) Isometric view from above

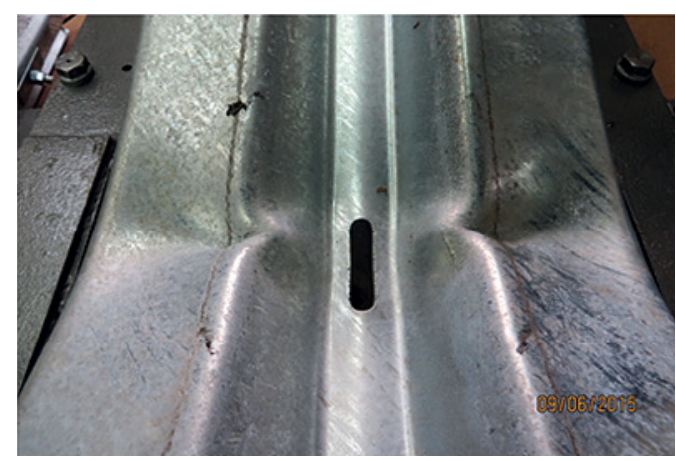

b) Close-up of the central section (in crosshead pressure area)

Figure 5. Final deformation of guide rail B segment

speed of $1 \mathrm{~mm} / \mathrm{s}$. The values of vertical displacement $s$, as well as force $F$, were recorded with a sampling frequency of $10 \mathrm{~Hz}$.

Figure 4 shows the $F(s)$ chart obtained in a bend test of the validation segment with segment deformation shown from the side view, every $50 \mathrm{~mm}$ displacement of the crosshead. The segment load-bearing capacity is $22.20 \mathrm{kN}$ at $31.30 \mathrm{~mm}$ displacement of the crosshead. The energy absorbed during bending is $4.48 \mathrm{~kJ}$. The initial stiffness of the validation segment (up to $15 \mathrm{~mm}$ displacement of the crosshead) is $1.36 \mathrm{kN} / \mathrm{mm}$. Figure 5 shows the final deformation of the segment after removing the crosshead. Local buckling curvature of the guide rail is visible.

\section{A numerical model of three-point bend test of $A$ and $B$ guide rail segments}

Geometric models of A and B guide rail segments of a length of $2.00 \mathrm{~m}$ were made using Catia v5r19 software. The numerical models were made using HyperMesh v13.0 software. The simulation calculations were performed using LS-Dyna v.971 finite element code. Figure 6 shows the discrete models of the three-point bend systems of A and B validation segments.

The guide rails meshed with finite elements of QUAD4 topology and average element dimensions of $25 \times 25 \mathrm{~mm}$ (in the rounding zones the average dimensions amount to $25 \times 10 \mathrm{~mm}$ ). The type A guide rail 


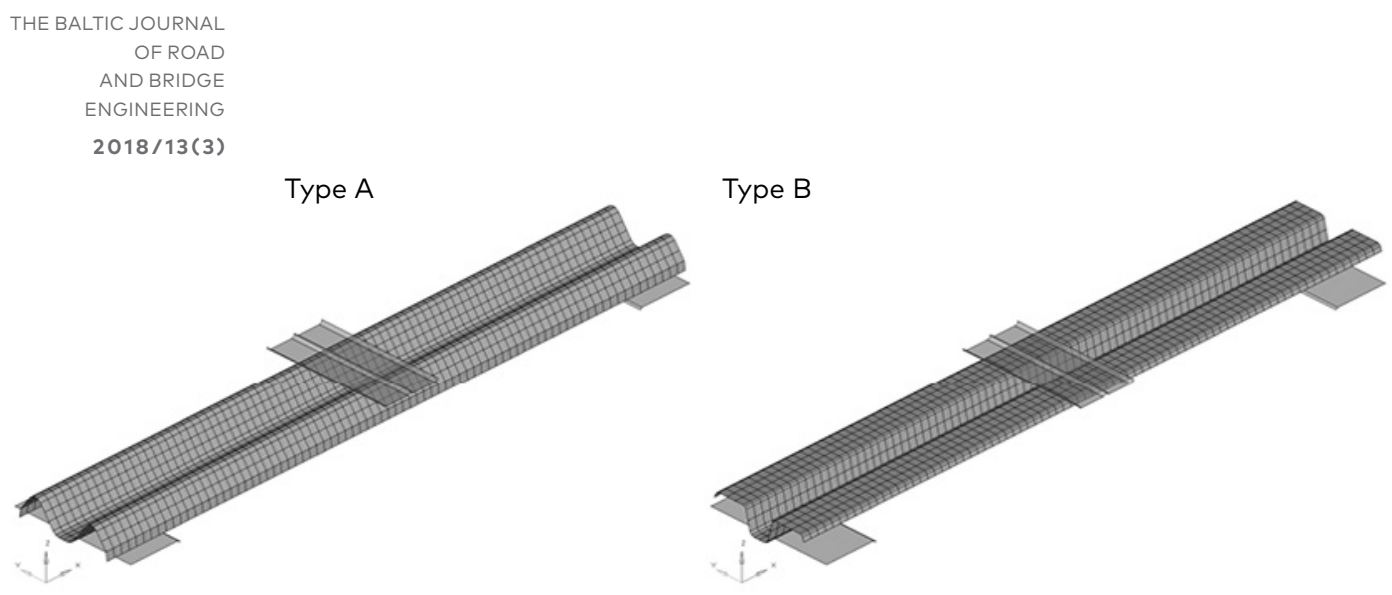

Figure 6. Numerical models of three-point bend systems of validation segments

meshed with 1920 finite elements (2025 nodes). The type B guide rail meshed with 2080 finite elements (2187 nodes). The loading block and the supports meshed with 720 finite elements (819 nodes) with QUAD4 topology and an average diameter of $20 \times 20 \mathrm{~mm}$ (in the rounding zones the average dimensions amount to $20 \times 6 \mathrm{~mm}$ ).

The finite element models of the guide rails were assigned the Belytschko-Tsai ELFORM-2 formulation (LS-DYNA 2006, 2007). This formulation is a four-node shell finite element with one in-plane integration point, using the Mindlin-Reissner plate theory. At the finite element thickness, five integration points were introduced. Due to the use of finite elements with reduced integration, the hourglass was controlled according to the Flanagan-Belytschko global stiffness procedure $(I H Q=4)$, with an hourglass coefficient of 0.03 (LS-DYNA 2006, 2007).

In the model, stiffness vibration damping was defined according to the Rayleigh proportional damping model of a damping factor of 0.03 . The contact model *CONTACT_AUTOMATIC_SURFACE_TO_SURFACE was defined between the punch/supports and the validation segment. The Coulomb friction model with coefficients of 0.25 and 0.09 for the static and kinematic friction respectively, was assumed. The model ${ }^{*}$ CONTACT FORCE_TRANSDUCER_PENALTY (LS-DYNA 2006, 2007) was defined to designate the loading force of the crosshead on the validation segments.

The mechanical properties of the steel guide rail (S235JR steel), as an isotropic material, were mapped using the material model ${ }^{*} \mathrm{MAT}_{-}$ PIECEWISE_LINEAR _PLASTICITY (LS-DYNA 2006, 2007). This model is an elastoplastic model with the ability to take into account the effect of the deformation rate (Cowper-Symonds model) as well as a failure model based on plastic deformation. The law of isotropic strengthening 
Table 2. Material constants of S235JR steel concerning material model *MAT_PIECEWISE_LINEAR_PLASTICITY (Klasztorny, Nycz, \& Szurgott, 2016)

\begin{tabular}{llll}
\hline $\begin{array}{l}\text { LS-DYNA } \\
\text { designation }\end{array}$ & Description & Unit & Value \\
\hline RO & material density & $\mathrm{t} / \mathrm{mm}^{3}$ & $7.85 \cdot 10^{-9}$ \\
\hline $\mathrm{E}$ & Young's modulus & $\mathrm{GPa}$ & 210.00 \\
\hline $\mathrm{PR}$ & Poisson's ratio & - & 0.30 \\
\hline SIGY & yield point & $\mathrm{MPa}$ & 372.00 \\
\hline ETAN & tangent modulus & $\mathrm{MPa}$ & 200.00 \\
\hline & $\begin{array}{l}\text { plastic deformation corresponding } \\
\text { to failure of finite elements } \\
\text { of accepted dimensions } \\
\text { (numeric parameter) }\end{array}$ & & \\
& & & \\
\hline
\end{tabular}

was implemented in the model. Table 2 lists the material constants of the guide rail (Klasztorny, Nycz, \& Szurgott, 2016).

The supports and the loading block were assigned the perfectly rigid body model *MAT_RIGID (LS-DYNA 2006, 2007). Young's modulus of $210 \mathrm{GPa}$ and a Poisson's ratio of 0.30 were used to determine the contact stiffness.

Due to the modelling of the quasi-static process in the environment for dynamic analysis, velocity-controlled excitation is applied to eliminate dynamic effects (elimination of initial acceleration), calculating speed from the Eq. (Hanssen, Hopperstad, Langseth, \& Ilstad, 2002):

$$
v(t)=\frac{\pi}{(\pi-2)} \frac{d_{\max }}{T}\left(1-\cos \left[\frac{\pi}{2 T} t\right]\right),
$$

where $v(t)$ - velocity-controlled excitation, $\mathrm{mm} / \mathrm{s} ; d_{\max }-$ maximum (final) displacement, mm; $T$ - loading duration, sec; $\mathrm{t}$ - time, sec.

\section{Results of modelling three-point bend tests of $A$ and $B$ guide rail segments}

Figure 7 shows a comparison of the $F(s)$ charts of the threepoint bending of $\mathrm{A}$ and $\mathrm{B}$ guide rail segments against the results of experimental bending of the guide rail B segment. Table 3 summarizes the values determined from the $F(s)$ charts. The symbols used are $F_{\max }$ - load-bearing capacity in N, $s$ - displacement corresponding to 


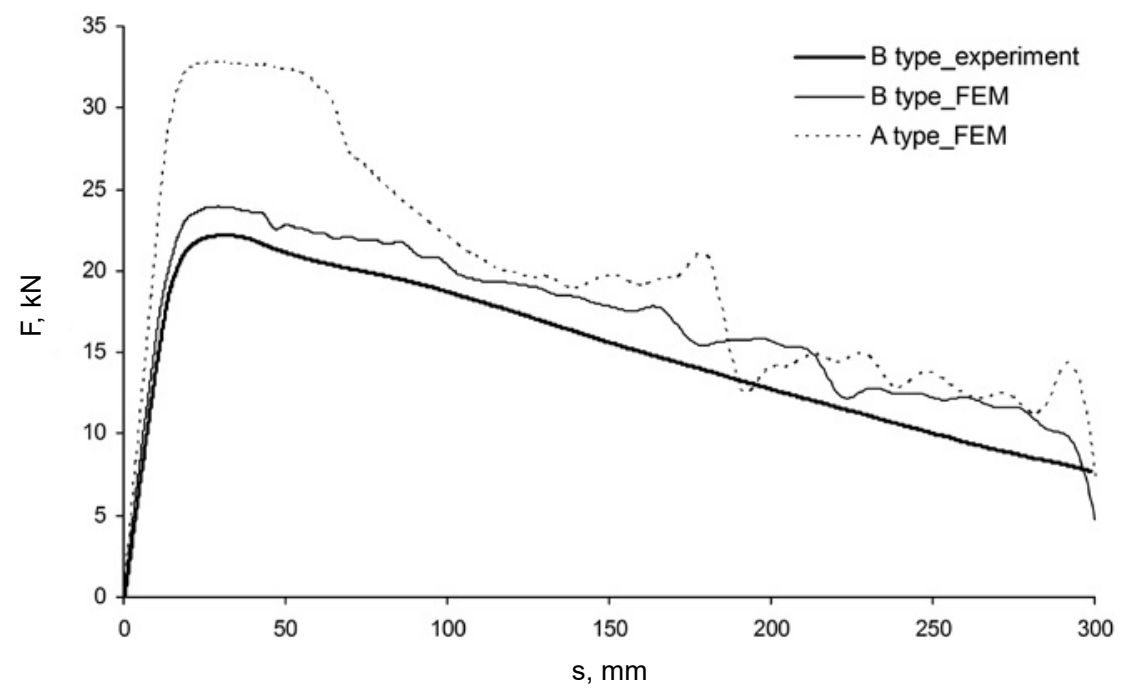

Figure 7. $F(s)$ graphs obtained from three-point bend test of $A$ and $B$ guide rail segments

the load-bearing capacity in $\mathrm{mm}, E$ - energy absorbed during bending (area under the $F(s)$ curve in the range of $0 \mathrm{~mm}$ to $300 \mathrm{~mm}$ ) in kJ. For the guide rail B segment one obtained a $7.50 \%$ more load-bearing capacity, a $7.00 \%$ fewer displacement corresponding to the load-bearing capacity, and $13.30 \%$ more absorbed energy than the experimental results, respectively.

The load-bearing capacity of the type A guide rail segment in the three-point bending test is $37.10 \%$ more than the load-bearing capacity of the guide rail B segment. At the same time, the energy absorbed by the guide rail A during bending is $17.20 \%$ more than it is for guide rail $B$. These results show the type A guide rail is stronger than the type B guide rail is during the three-point bending test. This property of the

Table 3. Characteristic values in three-point bend test of $A$ and $B$ guide rail segments

\begin{tabular}{cccc}
\hline Guide rail type & $\boldsymbol{F}_{\max }$ & $\boldsymbol{s}$ & $\boldsymbol{E}$ \\
& $\mathbf{N}$ & $\mathbf{m m}$ & $\mathbf{k J}$ \\
\hline A (FEM) & 32.90 & 30.10 & 5.94 \\
\hline B (experiment) & 22.20 & 31.30 & 4.48 \\
\hline B (FEM) & 24.00 & 29.10 & 5.07 \\
\hline
\end{tabular}




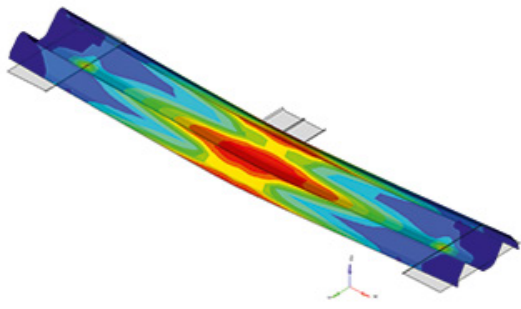

a) Type A

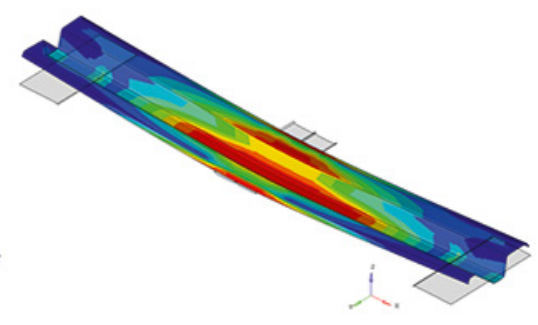

b) Type B

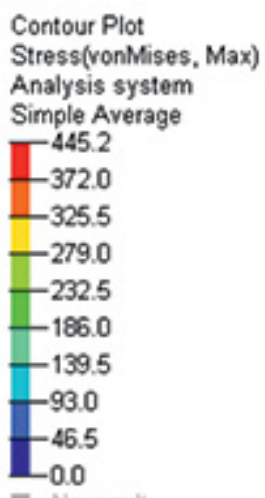

Figure 8. Huber-Mises-Hencky hypothesis-based effective stress in guide rails, corresponding to load-bearing capacity (isometric view from underneath)

gide rail $\mathrm{A}$ is evidenced by the initial part of graphs $F(s)$ up to the loadbearing capacity point.

Figure 8 shows Huber-Mises-Hencky hypothesis-based effective stress contour maps corresponding to the load-bearing capacity points for guide rails A and B, respectively. A significantly larger plasticization area (effective stresses above $372 \mathrm{MPa}$ ) is visible in the case of guide rail $\mathrm{B}$.

Figures 9 and 10 present the final deformation of the guide rails with isometric views from above and from underneath. In the case of guide rail $\mathrm{A}$, considerable bulging of extreme bends in the middle of the segment (under the punch) is visible. In the case of guide rail $B$, flattening of the cross-section under the loading block is seen.

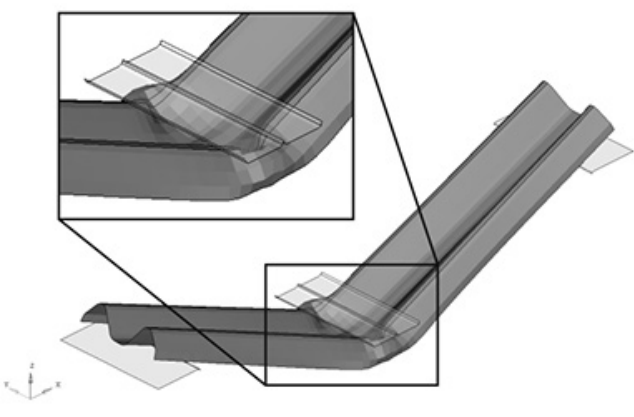

a) Isometric view from above

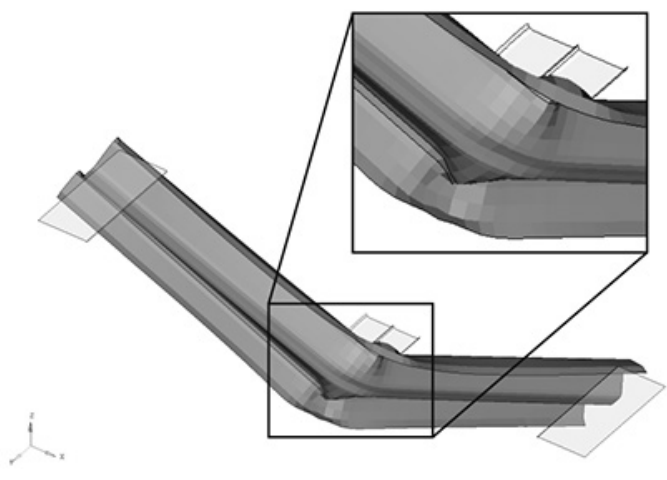

b) Isometric view from underneath

Figure 9. Final deformation of guide rail $A$ 


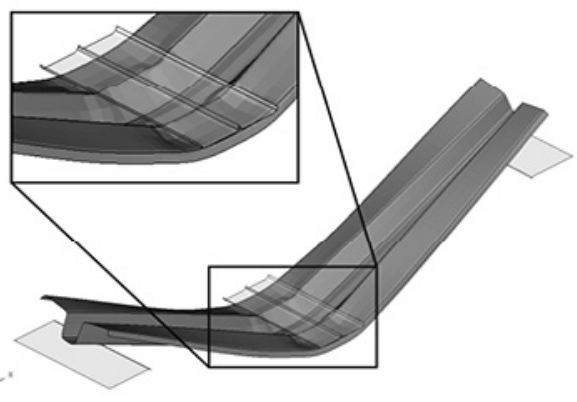

a) Isometric view from above

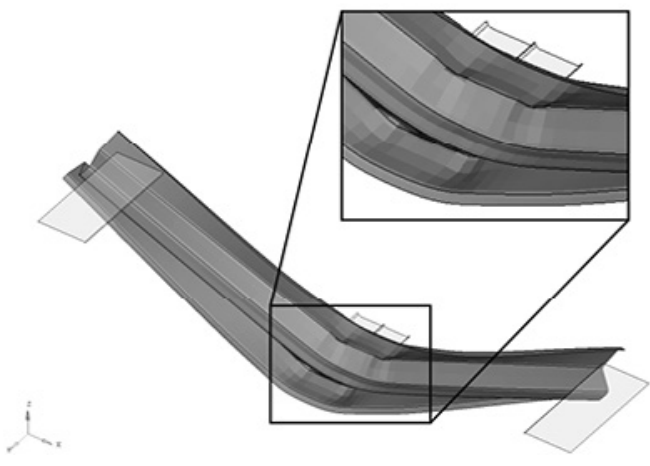

b) Isometric view from underneath

Figure 10. Final deformation of guide rail B

\section{Numerical model of simulated TB32 crash test}

A TB32 crash test simulation (a passenger car with a mass of $1500 \mathrm{~kg}$, colliding with the restraint system at $110 \mathrm{~km} / \mathrm{h}$, at a $20^{\circ}$ impact angle) for the SP-05/2 system (PN-EN 1317-2:2010) was conducted. The SP$05 / 2$ road barrier from Stalprodukt (2006) is composed of guide rail B segments, SIGMA-100 posts $1.90 \mathrm{~m}$ long and spaced by $2.00 \mathrm{~m}$, trapezoidal supporting elements for $\mathrm{B}$ guide rails and rectangular pads. The whole construction is joined with M16 screws with a spherical head and a nose, of a 4.6 strength class (Stalprodukt, 2006).

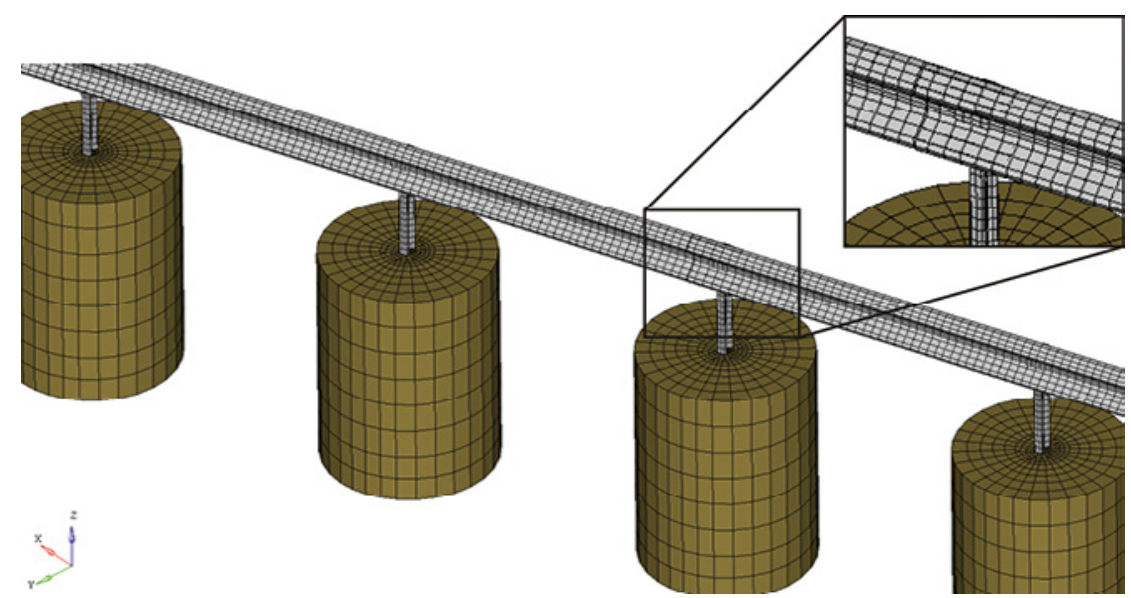

Figure 11. Fragment of analysed road barrier with type A guide rail 


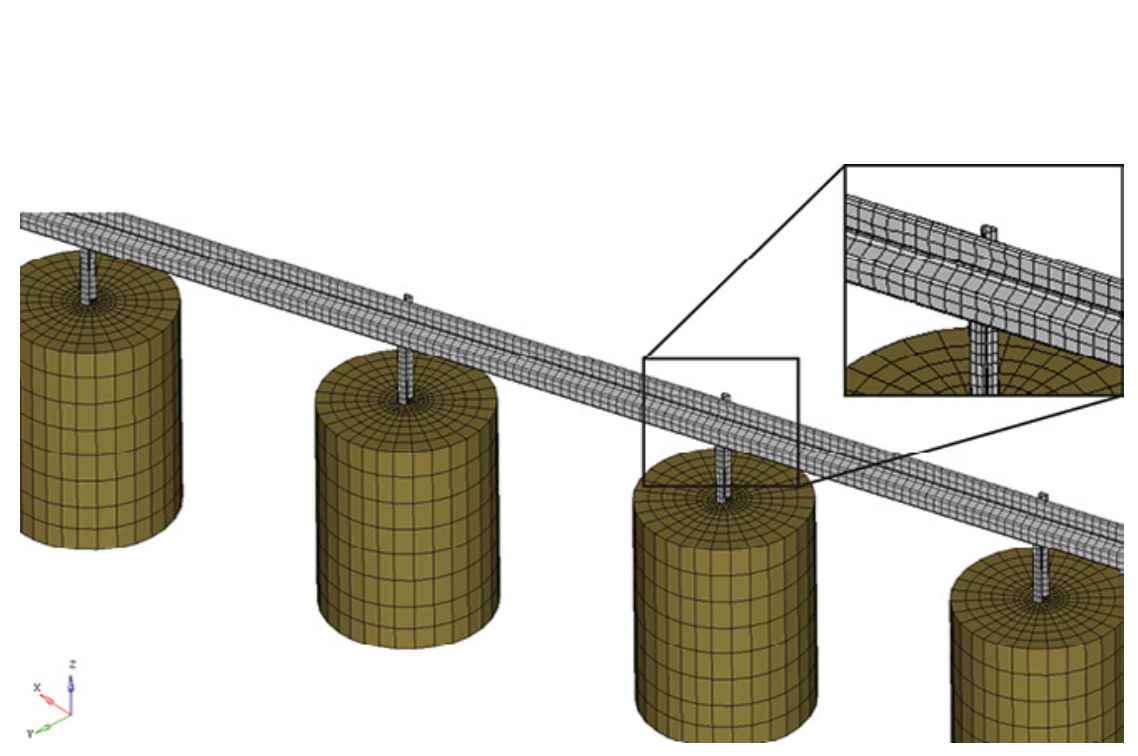

Figure 12. Fragment of analysed road barrier with type B guide rail

In order to test the influence of a guide rail type on the TB32 crash test, barrier SP-05/2 was modified accordingly. Guide rail B was replaced with guide $\mathrm{A}$ and supporting elements for A guide rails were introduced. The simulation crash test was performed on a $60 \mathrm{~m}$ long test barrier section (Klasztorny, Nycz, \& Szurgott, 2016). A 60 m long test system in two variants was used:

1. TB32-A - TB32 crash test, barrier with guide rail type A (Figure 11).

2. TB32-B - TB32 crash test, barrier with guide rail type B (Figure 12).

The methodology of the numerical modelling and simulation of crash tests was developed in the works (Klasztorny, Nycz, \& Romanowski, 2015; Klasztorny, Nycz, \& Szurgott, 2016; Nycz, 2015, 2016a, 2016b, 2016c). The models take into account the barrier ends, whose modelling approach is presented in the paper (Nycz, 2016c). The Dodge Neon vehicle model was taken from the public library of the NCAC and was subjected to necessary modifications (Klasztorny, Nycz, \& Szurgott, 2016).

\section{Results of TB32 crash test simulations}

Figure 13 shows a comparison of the energy balances of the TB32-A and TB32-B crash test simulations. Because of the collision of the Dodge Neon vehicle with the barrier, $61.00 \%$ of the kinetic energy of the vehicle is absorbed in the case of the TB32-A test and $60.00 \%$ of the kinetic energy of the vehicle in the case of the TB32-B test. The energy absorbed because of material destruction is $E=0.297$ MJ for the considered tests. 


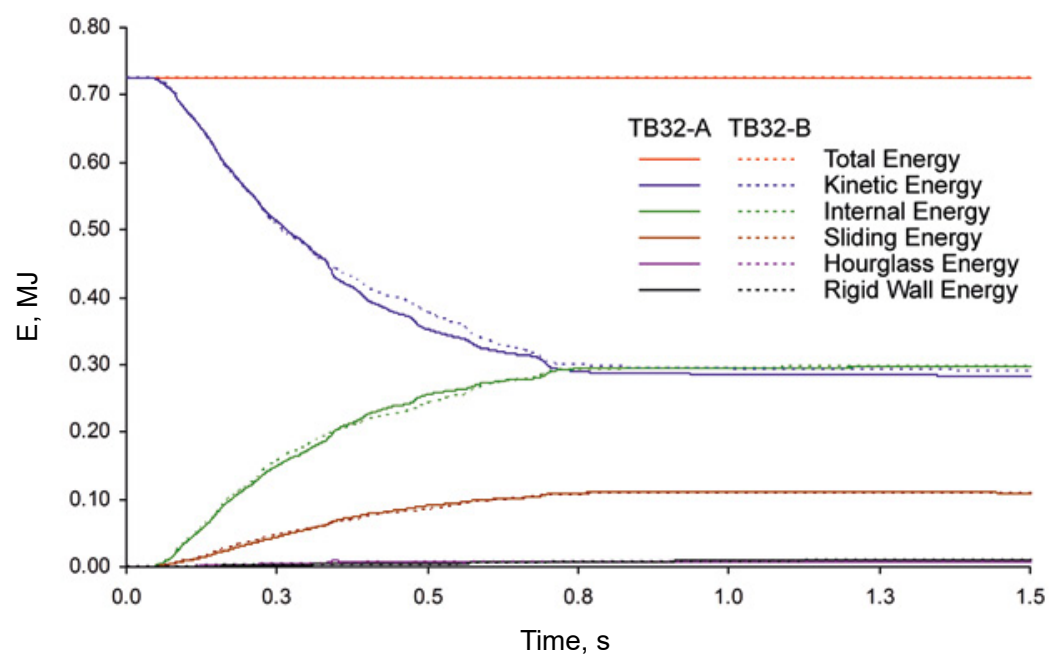

Figure 13. Comparison of energy balance for TB32-A (solid line) and TB32-B (dotted line)

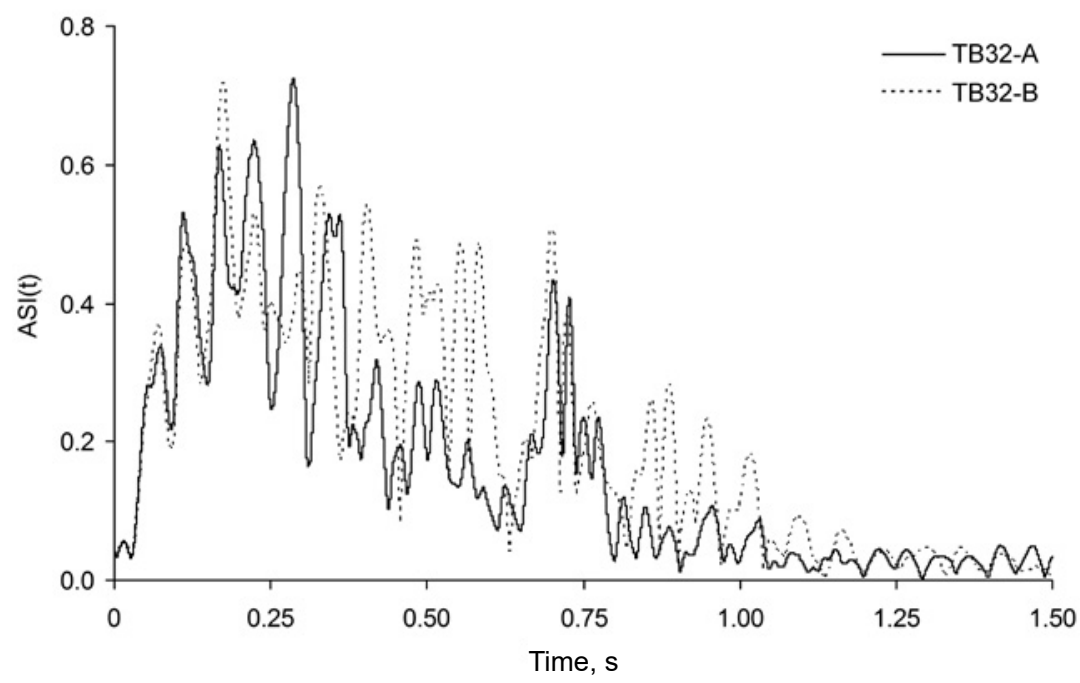

Figure 14. Comparison of ASI(t) graphs for TB32-A (solid line) and TB32-B (dotted line)

Table 4. Comparison of results of analysed crash tests

\begin{tabular}{ccccccccc}
\hline \multirow{2}{*}{$\begin{array}{c}\text { Dynamic } \\
\text { layout }\end{array}$} & \multirow{2}{*}{ ASI } & THIV & $\boldsymbol{W}$ & $\boldsymbol{L}$ & \multirow{2}{*}{ TEB } & & $\boldsymbol{E}$ & $\mathbf{v}_{\mathbf{r}}$ \\
\cline { 3 - 5 } \cline { 8 - 9 } & & $\mathbf{k m} / \mathbf{h}$ & $\mathbf{m}$ & $\mathbf{m}$ & & & $\mathbf{M J}$ & $\mathbf{k m} / \mathbf{h}$ \\
\hline TB32-A & 0.73 & 15.65 & 1.11 & 15.83 & correct & 0.297 & 69.40 \\
\hline TB32-B & 0.72 & 12.17 & 1.11 & 16.77 & correct & 0.297 & 70.90 \\
\hline
\end{tabular}


Vehicle residual velocity $v_{r}$ for the TB32-A test at the end of vehiclebarrier interaction ( $t=0.944 \mathrm{~s}$ ) amounts to $69.40 \mathrm{~km} / \mathrm{h}$. The residual velocity of the vehicle for the TB32-B test at the end of vehicle interaction with the barrier ( $t=0.904 \mathrm{~s}$ ) amounts to $70.90 \mathrm{~km} / \mathrm{h}$.

Figure 14 shows a comparison of the graphs of the collision intensity parameter $A S I$ as a function of time $A S I(t)$. The maximum value for the TB32-A test amounts to $A S I=0.73$ at $0.173 \mathrm{~s}$, and for the TB32-B test amounts to $A S I=0.72$ at 0.286 s. Figure 15 shows the configuration of the vehicle-barrier system at selected moments, respectively, for the TB32-A and TB32-B tests. The theoretical head velocity at the moment of collision with the cab was THIV $=15.65 \mathrm{~km} / \mathrm{h}$ for the TB32-A test and THIV $=12.17 \mathrm{~km} / \mathrm{h}$ for the TB32-B test. Figure 16 shows the length of contact of the vehicle with the barrier $L$ that amounts to $15.83 \mathrm{~m}$ for the TB32-A test and $16.77 \mathrm{~m}$ for the TB32-B test. Moreover, the trajectories of vehicle movement in the exit box are presented. The vehicle motion trajectories for the simulated crash tests satisfy the requirements of accepting the crash test. Working width $W$ amounts to $1.11 \mathrm{~m}$ for the

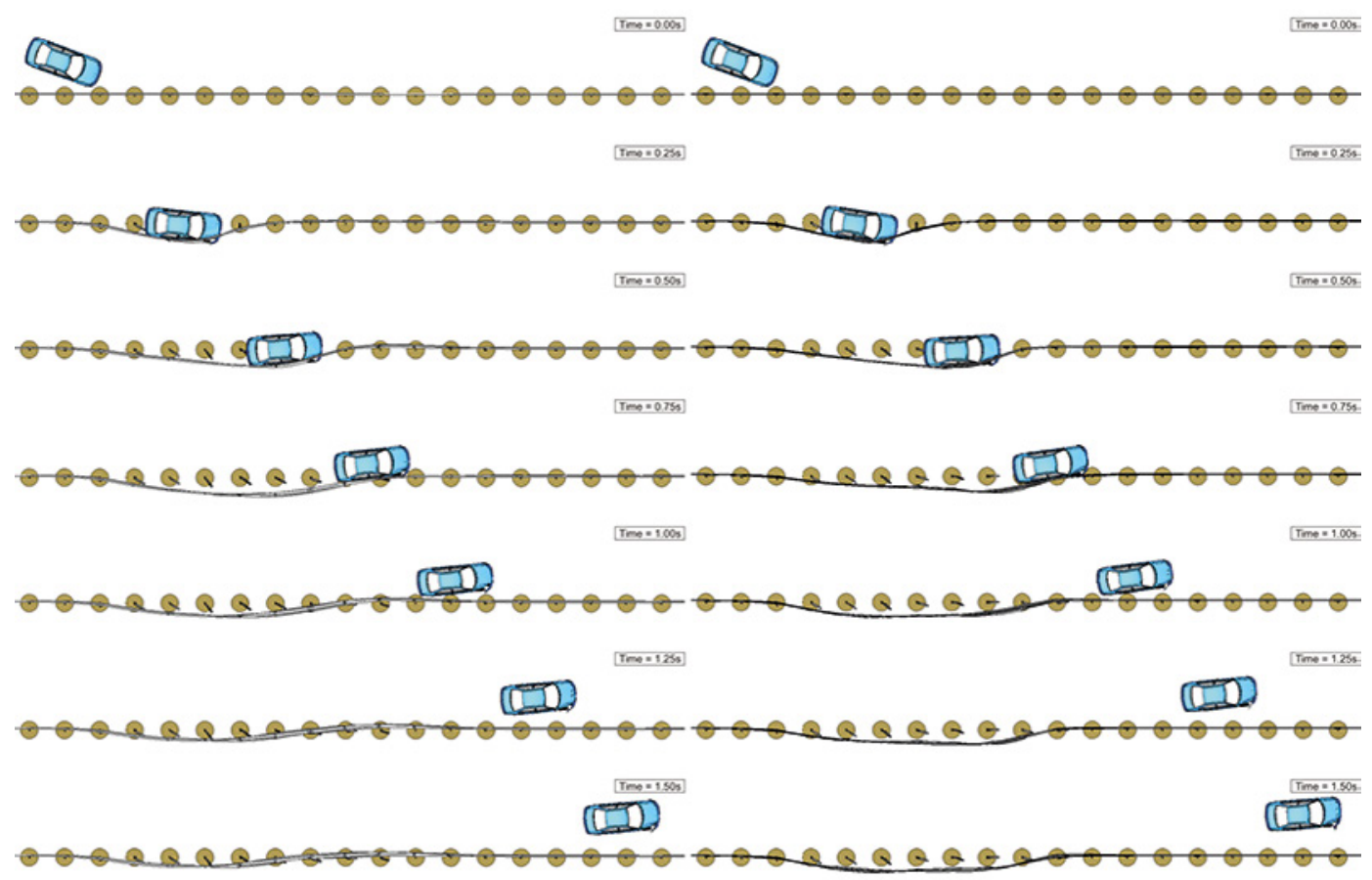
a) TB32-A
b) TB32-B

Figure 15. Crash test simulation (view from above) 


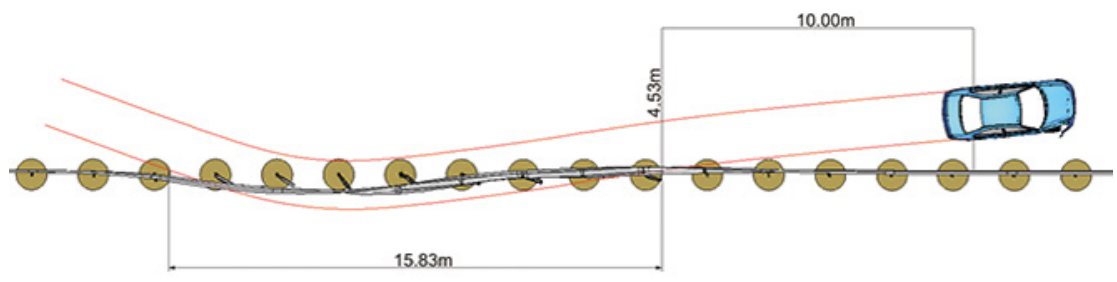

b) TB32-B

$10.00 \mathrm{~m}$

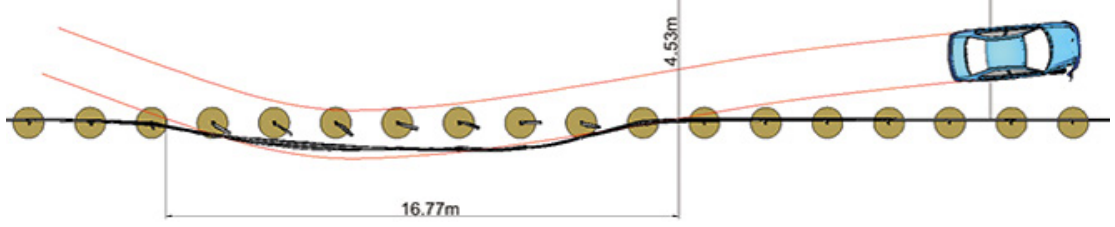

Figure 16. Vehicle repulse after collision with barrier, and length of vehicle contact with barrier (view from above)

two types of guide rails. The functionality parameters for crash tests TB32-A and TB32-B are summarized in Table 4. Abbreviation TEB means trajectory of the vehicle movement in the exit box.

For the simulated crash tests, the vehicle reflection criterion in the exit box is met. The values of working width $W$ and absorbed energy $E$, related to TB32-A and TB32-B tests, are the same. The ASI, THIV, and residual $v_{r}$ values for the TB32-A test differ slightly from respective values for the TB32-B test. The length of the vehicle contact with the barrier $L$ for test TB32-B is 5.90\% more than the length for test TB32-A. In the case of guide rail $B$, the damage to the connections of the posts to the guide rail is much more than it is for guide rail $\mathrm{A}$. It has been assessed that guide rail $\mathrm{A}$ is preferable to guide rail $\mathrm{B}$.

\section{Conclusions}

1. The numerical analysis of bending the validation segments of the guide rails shows that:

- the load-bearing capacity of guide rail $\mathrm{A}$ is $37.10 \%$ more than it is for guide rail $\mathrm{B}$;

- the energy absorbed during the bending of guide rail $\mathrm{A}$ is $17.20 \%$ more than it is for guide rail B;

- the shape of the deformation of the two guides is different.

2. The TB32 crash tests performed for type A and B guide rails have shown that: 
- the vehicle reflection criterion in the exit box is met for type A and B guide rails;

- the Acceleration Severity Index, Theoretical Head Impact Velocity, Working Width, energy absorbed and residual velocity parameters corresponding to the TB32-A and TB32-B tests differ slightly;

- the use of guide rail type B increases the length of the vehicle contact with the barrier by $5.90 \%$;

- there are more broken post-guide rail screw connections in the barrier with guide rail B than it is for the barrier with guide rail A.

3. It was assessed that guide rail A is superior to guide rail B taking into account all the performance parameters of the road safety barrier.

\section{Acknowledgements}

This work was supported by a grant from the National Centre for Research and Development, Poland (Grant Number PBS1/B6/14/2012). Mrs. Christine Frank-Szarecka, Canada, provided a translation of the article.

\section{REFERENCES}

Atahan, A. O. (2002). Finite element simulation of a strong-post W-beam guardrail system. Simulation, 78(10), 587-599. https://doi.org/10.1177/0037549702078010001

Borovinšek, M., Vesenjak, M., Ulbin, M., \& Ren, Z. (2006). Simulating the impact of a truck on a road-safety barrier. Strojniski Vestnik, 52(2), 101-111.

Borovinšek, M., Vesenjak, M., Ulbin, M., \& Ren, Z. (2007). Simulation of crash tests for high containment levels of road safety barriers. Engineering failure analysis, 14(8), 1711-1718. https://doi.org/10.1016/j.engfailanal.2006.11.068

GDDKiA (2001). D-07.05.01 Bariery stalowe ochronne (in Polish)

Hanssen, A. G., Hopperstad, O. S., Langseth, M., \& Ilstad, H. (2002). Validation of constitutive models applicable to aluminium foams. International journal of mechanical sciences, 44(2), 359-406. https://doi.org/10.1016/S0020-7403(01)00091-1

Klasztorny, M., Nycz, D. B., \& Szurgott, P. (2016). Modelling and simulation of crash tests of N2-W4-A category safety road barrier in horizontal concave arc. International Journal of Crashworthiness, 21(6), 644-659. https://doi.org/10.1080/13588265.2016.1212962

Klasztorny, M., Nycz, N. B., \& Romanowski, R. K. (2015). Rubber/foam/composite overlay onto guide B of barrier located on road bend. Archiwum Motoryzacji, 69.

LS-DYNA (2006). Theory Manual. Livermore Sofware Technology Corporation. $680 \mathrm{p}$. 
LS-DYNA (2007). Keyword User's Manual. Livermore Sofware Technology Corporation. $680 \mathrm{p}$.

Mikołajów, L. (2006). Drogowe bariery ochronne, Magazyn autostrady 8-9: 14-18. Available from the Internet: http://viamens.pl/artykuly/ autostrady_2006_08_str014.pdf (in Polish)

Nasution, R. P., Siregar, R. A., Fuad, K., \& Adom, A. H. (2009, October). The effect of ASI (Acceleration Severity Index) to different crash velocities. In Int. Conf. on Applications and Design in Mechanical Engineering (ICADME), CD Proc. 1-6. Malaysia (pp. 11-13).

Nycz, D. (2015). Modelowanie i badania numeryczne testów zderzeniowych bariery klasy N2-W4-A na łukach dróg. Ph.D. Thesis. WAT Press. 242 p. (in Polish)

Nycz, D. B. (2016a). Effect of the B-type guiderail joints of a road barrier on the TB11 and TB32 virtual crash tests. Archiwum Motoryzacji, 71(1).

Nycz, D. B. (2016b). Influence of impact angle and humidity on TB11 virtual crash tests for SP-05/2 road safety barrier. Archiwum Motoryzacji, 73(3).

Nycz, D. B. (2016c). Modelowanie końcówek odcinka bariery SP-05/2 do zastosowania w symulacji testów zderzeniowych, Modelowanie Inżynierskie, 29(60), 44-51. Available from the Internet: http://kms.polsl.pl/mi/ pelne_29/06_29_60.pdf (in Polish)

PN-EN 1317-2:2010 Systemy ograniczajace droge - Część 2: Klasy działania, kryteria przyjęcia badań zderzeniowych i metody badań barier ochronnych $i$ balustrad (in Polish)

PN-EN 1317-5+A2:2012 Systemy ograniczające drogę - Część 5: Wymagania $w$ odniesieniu do wyrobów i ocena zgodności dotycząca systemów powstrzymujacych pojazd (in Polish)

Ren, Z., \& Vesenjak, M. (2005). Computational and experimental crash analysis of the road safety barrier. Engineering Failure Analysis, 12(6), 963-973. https://doi.org/10.1016/j.engfailanal.2004.12.033

Stalprodukt S. A. (2006). Stalowe bariery ochronne. Steel safety barriers. Bochnia, Poland. 124 p. Available from Internet: http://cdn13.pb.smcloud.net/t/ files/19/19/1d/d39f1f61fc/stalowe-bariery-ochronne-stalprodukt.pdf

Transportation Officials. Task Force for Roadside Safety. (2011). Roadside design guide. AASHTO. 